\title{
Researcher development in universities: Origins and historical context
}

\author{
Asher Rospigliosi* and Tom Bourner - University of Brighton, UK
}

\begin{abstract}
This article explores the origins of researcher development in British universities. Its principal aim is to provide a coherent, and reasonably succinct, account of the evolution and development of researcher development that is as consistent as possible with what is known about the development of the Western university, the history of the research doctorate and the emergence of the research university. The main conclusion is that the origins of researcher development in the modern university can be found in the philology of the early modern university, which in turn emerged from the accumulation of knowledge in Western Christendom from other places and other times. Other conclusions are that there was little researcher development in the medieval university, and that the 'traditional' model of researcher development, centred on the PhD, is much more recent than is commonly supposed, so that, from a long-term perspective, the 'traditional model' may be but one stage in its continuing development. The article also develops a model that locates researcher development within a series of intellectual contexts: from the research process itself, to the advancement of knowledge more generally, and, finally, to changes in conceptions of knowledge itself.
\end{abstract}

Keywords: researcher development; philology; Humboldt; PhD; research seminar; mode 2 knowledge

\section{Introduction}

This article is about the origins of researcher development in British universities. It aims to provide a resource for those who wish to research in the emergent field of researcher development, and those interested in innovation in the practice of researcher development, by providing the historical context within which to frame their work. It seeks to clarify where researcher development in universities is coming from, literally and metaphorically. It offers a single source of knowledge about the origins and history of researcher development across all the stages of development of the Western university from the Middle Ages to the start of the twenty-first century.

There are several reasons why this is an important issue. First, the emergence of the researcher developer as a third-space profession (Whitchurch, 2008) has enhanced the significance of enquiry and innovative practice in researcher development and its historical context. Second, the increasing importance of knowledge in the modern world is recognized in the popularity of the term 'knowledge society'; the development of a knowledge society underlines the importance of research, and hence also the importance of researcher development. Third, the position of the PhD is facing potential challenges from other forms of researcher development including, for example, the emergence of the MRes, the filtering down of researcher development 
into master's degrees in the last third of the twentieth century and, following that, into the upper years of undergraduate programmes (Bourner et al., 2014). Also, at a more conceptual level, there is the recognition of mode 2 knowledge (Gibbons et al., 1994). More generally, the rationale for the article can be summarized in the words of Chaim Potok (1985): 'If you don't know the past you can't understand the present and plan properly for the future.'

\section{Background}

Researcher development in British universities is a very recent phenomenon. Google's Ngram viewer shows that the overwhelming majority of occurrences of the term 'researcher development' has taken place in the twenty-first century (Google Books Ngram, 2019). This raises the question of the origins and evolution of researcher development. This article reports the results of a quest for the origins of researcher development in Britain.

Our enquiry took us back to the beginnings of the Western university, as it is possible that the reason(s) for the emergence of universities could have enduring relevance down the ages to the current purpose(s) of universities, including their contribution to the advancement of knowledge. It finishes at the end of the twentieth century because it is not our intention for this article to become involved in the current debates on researcher development. Indeed, our intention in producing this article is to provide the historical context within which these current debates can be framed.

This article adopts a chronological approach, evaluating what we know about researcher development in each of the three main stages of the Western university. These stages are: the medieval university; the Renaissance and early modern university; and the modern university, which emerged in the nineteenth century. This is the consensus model of the main developmental stages of the Western university. It was, for example, the categorization used by the (now) European University Association (EUA) for their monumental A History of the University in Europe (De Ridder-Symoens, 1992, 1996; Rüegg, 2004).

For the purposes of this article, 'researcher development' is defined as the enhancement of the capacity and disposition to engage in research. We define research as the intentional accumulation of new knowledge. Research is not the same as scholarship, and we follow Lewis Elton (1992) in defining scholarship as the critical interpretation of existing knowledge.

We started, of course, by searching the literature for an already existing history of researcher development, but we were unable to find any single publication on the history of researcher development per se. However, we found a large literature on the history of universities (including, for example, the volumes of the EUA cited above), another large literature on the history of the research doctorate (including, for example, the seminal works of Renate Simpson, 1983, 2009, on the development of the $\mathrm{PhD}$ in Britain) and another body of work on the history of the research university (including, for example, Clark, 2006 and Axtell, 2016). The task we set ourselves was to distil a coherent, and reasonably succinct, account of the history of researcher development in universities, particularly in Britain, that is as compatible as possible with these literatures. 


\section{Researcher development in the medieval university}

During the eleventh and twelfth centuries, the Latin Church was growing geographically and in influence, power and authority over the lives of people of Latin Christendom (Bartlett, 1993). Consequently, it needed more literate and educated clerics for its extending reach and expanding work. In 1079, Pope Gregory VII instructed all cathedrals to establish cathedral schools (Grant, 2004). Most of the earliest universities of Europe had their origins in these cathedral schools (Pedersen, 1997). Their teachers were in holy orders, and their primary purpose was to provide an education that would prepare students for service to the Latin Church. Not all those who enrolled at such institutions, however, became clerics, any more than current students who enrol on history degrees necessarily go on to become historians. The growing reliance on written records in the twelfth and thirteenth centuries enlarged the number of opportunities for employment of literate and university-educated people (Rospigliosi et al., 2016).

Students were initially enrolled in the faculty of arts, where their studies were centred on the words of the Bible, which for many people in the Middle Ages (and later) contained the literal words of God (McGrath, 2001), other scriptural texts, particularly the teachings of the major Church fathers, and the trivium (comprising grammar, reasoning (dialectic) and rhetoric), followed by the quadrivium (comprising arithmetic, geometry, astronomy and music). Medieval universities offered doctorates, but not as a research degree (Cobban, 1975). Originally, the master's degree and the doctorate were equivalent terms for a university teacher, with some variation by region and by faculty. Initially, the title of doctor was preferred in the universities of southern Europe and the title of master was favoured in the universities of northern Europe. The arts, philosophy and theology faculties preferred master, and medicine and law preferred doctor. In theology, the title doctor did not replace master until the fifteenth century. 'In 1476, the dean of the arts faculty at Leipzig felt the need to remind people, "The master of arts is the same as the doctor's degree"' (Clark, 2006: 188).

In order to explore researcher development in the medieval university, it is necessary to understand research in the medieval university, and in order to understand research in the medieval university, it is necessary to understand the advancement of knowledge more generally, which, in turn, means looking at the nature of knowledge in the medieval university.

\section{Knowledge in the medieval university}

The primary source of knowledge in the medieval university was text. This is not surprising, as Latin Christianity was a text-based religion and the medieval university was an institution of the Latin Church staffed by clerics of the Latin Church. Islamic scholars referred to Christians as 'people of the book' (Burnett, 1997). For the most part, the texts themselves were not challenged as they were sanctioned as 'holy scripture' by the Latin Church (Turner, 2014).

There was a hierarchy of esteem among domains of knowledge within the medieval university, in which spiritual (sacred) knowledge occupied a higher place than secular (profane) knowledge. This is reflected in recognition of theology as the 'queen' of the academic subjects (Hannam, 2009). Secular knowledge was relatively unimportant, at least compared to knowledge of the heavenly realm, that is, spiritual knowledge. The Christian Church had traditionally held a low opinion of the pursuit of secular knowledge. Indeed, the pursuit of earthly knowledge had been denounced by St Paul who had the most influence on the development of Christianity other than 
Jesus himself. And St Augustine who, in the Middle Ages, was the leading figure among the Christian fathers had associated the acquisition of earthly knowledge with the sin of pride (Freeman, 2002).

However, it was apparent that a significant part of the success of Islam, in the centuries up to the eleventh century, lay in its superior secular knowledge and that, in this earthly realm, knowledge is power. Consequently, the Latin Church developed an interest in acquiring the secular knowledge possessed by Islamic countries, particularly their practical and scientific knowledge. The unlocking of this secular knowledge in a way that was consistent with the Christian Church was entrusted to the learned clerics who were expert in the interpretation of Christian scripture, that is, those clerics who prepared students for the priesthood, mainly found in the universities of Europe (Hannam, 2009).

\section{The advancement of knowledge}

The modern idea that a university education is a vehicle for the dissemination of new knowledge was largely unknown to medieval university education. There was relatively little accumulation of new knowledge within university education during the Middle Ages, as evidenced by the stability of texts. Many of the texts, such as Peter Lombard's Sentences, first used in the twelfth century, were still in use three hundred years later in the fifteenth century (Harkins, 2015). The greatest advance in knowledge was the result of accumulation of knowledge within Western Christendom from other places (particularly Islamic countries) and other times (particularly ancient Greece). Most of that 'new' knowledge was in the fields of the natural sciences, medicine, philosophy and mathematics.

\section{Research}

If research is the systematic accumulation of new knowledge, then there was very little in the Middle Ages. But the origins of research can be seen in the addition to knowledge available within Western Christendom from the texts from Islamic countries, many of which originated in ancient Greece (Burnett, 1997). Such knowledge was text-based, and most had been copied many times and had been translated into another language at least twice (into Arabic and then into Latin); much was incomplete or fragmentary, and some texts were forgeries (Hiatt, 2004). This meant that those who were responsible for integrating it into the body of knowledge within Western Christendom, mostly university scholars, had the problem of establishing its authenticity, original form and meanings. Tackling these problems led to the development of practices that would form the basis of the theory and practice of philology in the Renaissance and early modern university (Turner, 2014).

\section{Researcher development}

How did medieval scholars learn how to establish the authenticity, original form and meanings of the new texts? First, it is important to recognize that most medieval academics were engaged in scholarship, applying logic to the accepted texts of the Latin Church, rather than in research. For the small minority who were engaged in research, there appears to have been no explicit training or development. These medieval scholars did not have access to the philological methods that had been developed in the ancient world (Turner, 2014). This means that they were reduced to hard experience and following the successful practices of others who were also engaged in this work. By the late Middle Ages, a body of practices had been developed that represented an 
embryonic form of philology. Perhaps the most famous example of the use of these practices was in the exposure of the Donation of Constantine as fraudulent by Lorenzo Valla in 1440 using recognized philological methods. The Donation of Constantine was a forged decree whereby the Emperor Constantine was supposed to have passed over imperial authority of the western part of the Roman Empire to the Pope.

The main conclusion is that the medieval university produced trained scholars skilled in the interpretation of accepted texts, but not trained researchers.

\section{Researcher development in the Renaissance and early modern university}

By the end of the medieval period, the university 'project' had lost its impetus. Green (1974: 31) writes of Oxford in the late medieval period:

In the fifteenth century the university entered into ... a period of contraction. Its numbers apparently fell from 1,500 to 1,000; only 27 men took the masters' degree in 1456-7. Contemporary letters complained of the shortage of students, teachers and endowments.

There are many reasons for this decline, including the corruption in the Latin Church in the fourteenth and fifteenth centuries, which was increasingly apparent. The goal of providing a higher education that would prepare people for service in the Latin Church therefore became less compelling, and certainly less uplifting. In these later years of the Middle Ages, service to the Latin Church was a less inspiring vision for universities and a less inspiring vocation for talented young men. Consequently, student numbers fell and recruitment became more difficult, which resulted in financial difficulties for the universities (Cobban, 1988).

The fall in student numbers led to a reassessment of the priorities of universities. Instead of focusing on the provision of an educated clergy for the Latin Church, they increasingly shifted their focus on to providing a higher education for sons of the relatively affluent. The need to recruit students and generate fee income shifted the mission of universities in a more student-centred direction. The European university became more responsive to emerging developments within Europe, including the Renaissance, the growth of the nation state and the growth of literacy. The university curriculum was extended to reflect the growing interest of the literate classes in the Italian Renaissance and humanistic studies. The spirit of the Renaissance was to seek and preserve the best from across the whole history of civilization, believed, at that time, to have had its origins in ancient Greece (Alexiou, 1990; Miles, 2010).

The Renaissance opened up a range of new occupations and increased opportunities within some existing professions, including those of archivists, antiquarians, librarians, curators and personal assistants to those involved in the intellectual revolution in Europe that the Renaissance represented (Rospigliosi et al., 2016). This provided the impetus for the adoption of classical studies within the university that became such an important part of university education for centuries to come. The growth of literacy in Europe in the early modern period also created a rising demand for teachers, a demand that was satisfied by an increasing number of new graduates. The rise of the nation state in Europe also created new forms of employment for literate professionals. Larger political units created the need for administrators, diplomats and other civil servants. An indication of the growing role of university graduates in governing the new nation state can be found in their increasing numbers in the House of Commons: in 1563, only 67 members had a 
university education; by 1593, only three decades later, the number had risen to 160 (Curtis, 1959: 59).

In order to see where researcher development fitted into these transformed institutions, it is necessary to look at its wider context of research. And in order to see where research fitted into its wider context of the advancement of knowledge more generally, it is necessary to look at the still wider context of knowledge itself.

\section{Knowledge in the Renaissance and early modern university}

The decline in the power and esteem of the Latin Church in the late Middle Ages inevitably brought with it a decline in the esteem of spiritual knowledge relative to secular knowledge. At the same time, the Renaissance elevated the esteem of knowledge drawn from ancient Rome and Greece. What counted as knowledge, as far as university education was concerned, continued to be text-based. There was a prima facie case that knowledge that had survived for centuries, even millennia, was of more value than new knowledge that may prove transient. Early Renaissance scholars, such as Petrarch, accumulated manuscripts from monasteries across Europe. The Renaissance disposition to collect, preserve and accumulate is evidenced by the emergence of the 'cabinet of curiosities', the 'room of wonders', the building of galleries and the development of museums. The Renaissance turned the common human impulse for acquisition towards the accumulation of knowledge. It was from this time that the notion of contributing to the stock of knowledge became a recognizable and selfaware activity (Burke, 2016).

\section{The advancement of knowledge}

The key element in the birth of the Renaissance was the recovery of products of the human mind from ancient Rome and Greece. This was not, of course, new knowledge; it was very old knowledge, but it was new to the universities of Europe. A significant dimension of this development is that it constituted an expansion of text-based knowledge far beyond texts that were of particular concern to the Latin Church (Burke, 1997).

The new texts from ancient Rome and Greece offered an alternative source of authority, belief and moral justification - key issues for university education of the Renaissance. If universities aspired to produce graduates who could tell right from wrong morally, intellectually and aesthetically, then these were key texts. And if a university education was to introduce young men to the products of the finest minds from the whole of Western civilization, then they were even more important. The accumulation of knowledge became an increasingly important part of the advancement of knowledge in the Renaissance and early modern university. Whereas the medieval universities aspired to the pursuit of truth, Renaissance and early modern universities were more focused on the pursuit of knowledge.

The recovery of this knowledge was not, however, unproblematic. In many cases, the original documents were destroyed or lost, and the recovered texts were copies of varying quality and many were forgeries (Hiatt, 2004). Often, the recovered texts were translations, which introduced further sources of error or misinterpretation. The need to resolve problems of this kind gave rise to the development of the philological practices from the medieval university into a key discipline of the early modern university.

The development of philology implied a move away from allegorical interpretation of text and towards a more literal interpretation of text and hence knowledge. The main goal of Renaissance philology was to accumulate knowledge and wisdom from 
texts recovered from ancient Rome and Greece, but it was only a matter of time before the methods of philology were applied to scripture and documents of the Latin Church itself. The weakened Latin Church was unable to prevent this, and the universities had become much more independent. There is therefore a direct link from the development of philology to challenges to the Latin Church's interpretation of scripture and related Church-based documents, to new translations of scripture and translations into the vernacular languages of Europe. Philology thus played an important part in the events that would lead to the Reformation.

\section{Research}

Universities of the Renaissance and early modern period were mostly concerned with the education of young gentlemen, and with knowledge that could impact on that education. Universities sought to discover and then convey an appreciation of the 'best which has been thought and said in the world' (Arnold, 1869: viii). In the context of the Renaissance and early modern world, that meant the fruits of the finest minds of Western civilization throughout the ages and that meant discovering such fruits and working on them to eliminate errors from inaccurate copying and misinterpretations in translation, as well as exposing fraudulent documents. This implied the development of philological skills.

The first philological skill was textual analysis. This involved work focused on words and comparison of words from different versions of the same document, checking for anachronisms, mistranslations and so on. The strategy of gaining knowledge and understanding of a text by examining its individual words as parts of that text can be recognized as a reductionist approach. The outcome was often a new edition or a new translation of an old text. A good example of this work and its significance is the new translation of the New Testament from the Greek by Erasmus.

The second major philological strategy and skill was contextual analysis. According to philologists, in order to really make sense of texts from bygone ages or faraway places, it was necessary to understand the context(s) in which they were written. It was necessary to understand the societies in which they were produced, their historical circumstances and the motivations of those who produced them. The study of these contexts would eventually produce separate new fields of study within the broader domain of the humanities, such as history, and separate fields of study within the broader domain of the social sciences, such as anthropology (Turner, 2014).

As well as contextual analysis and the reductionism of textual analysis, philology developed methods of comparative analysis that eventually played an important role in the rise of linguistics as a separate discipline. Philology also played a crucial role in the development of critical thinking: 'Philology in Europe was, at its zenith, one of the hardest sciences on offer, the centrepiece of education and the sharpest exponent if not the originator of the idea of "critical thinking"' (Pollock, 2009: 931). Philology asked classic questions that defined critical thinking, such as, 'who is the author of the text?', 'what were their motivations and interests?' and 'what assumptions would have been made in the time and place that it was written?'

\section{Researcher development}

The lack of impact of the scientific revolution on university education has often been noted (see, for example, Ashby, 1958). This has been taken as evidence of the backwardness of university education and universities in general in the seventeenth and eighteenth centuries. This is unfair, because the primary goal of the Renaissance 
and early modern university was to offer a university education that would equip young gentlemen for lives after university, and it was not clear how the physical sciences could play a part in the lives of the large majority of such young men. In England, for example, most graduates of Oxford and Cambridge would go on to positions in the Anglican Church and it was by no means obvious that the latest knowledge of the natural sciences would contribute to that vocation. It was much more important that such graduates be equipped with text-based knowledge from Judeo-Christian sources and the ancient world. Mainstream research in this context was, therefore, philological.

Researcher development meant, for the most part, the development of philological skills, which flourished in the early modern university, particularly in Germany (Bod, 2013; Turner, 2014). It was there that philological training in textual analysis, contextual analysis and comparative analysis was most advanced. It was there also that critical thinking reached its highest level of development in the early modern world, and it was there that the academic seminar was developed as the primary vehicle for developing those skills (Clark, 1989). Clark (2006: 174) provides a good account of how the philological seminar in German universities provided a 'methodological training, practice in grammatical analysis, textual interpretation, and critique'.

\section{Researcher development in the modern university}

In the eighteenth century, higher education in the Western university was again stagnating:

By the eighteenth century universities everywhere were in the doldrums, confined to the training of priests or pastors, a few civil servants, and those gentry too poor to educate their sons by private tutors and the increasingly popular 'grand tour' of the Continent ... most universities in eighteenth century Europe were moribund, with idle professors ... despised by the intellectuals of the Enlightenment. (Perkin, 1997: 14-15)

The main exception to this picture was the field of philology, which flourished in eighteenth-century German universities. Bod (2013: 143) describes philology as the 'queen of early modern learning'. This contrast was particularly striking as German universities were otherwise regarded as among the most backward in Europe in the eighteenth century (Perkin, 1997).

The solution to the increasing irrelevance of universities arrived in the form of Wilhelm von Humboldt, who led the second great transformation in the main goal of the university. Humboldt was a philologist and statesman who was appointed, in 1808, to be director of the education section within the Prussian ministry of the interior. According to his philosophy, it was not the purpose of the university to serve the needs of students, but rather it was the purpose of the students as well as the staff of the university to serve the pursuit of knowledge itself. In Humboldt's own words (in translation): 'At the highest level, the teacher does not exist for the sake of the student: both teacher and student have their justification in the common pursuit of knowledge' (Humboldt, 1970: 243). That was significantly different from the erstwhile university education of the Renaissance and early modern university.

The new University of Berlin statutes established a doctor of philosophy degree above the master of arts award. In addition to a written examination, candidates for the doctor of philosophy degree had to produce a written dissertation and defend it. The written dissertation was not new in German universities, but previously it had been evaluated in terms of its erudition and the extent of knowledge displayed; at 
Berlin, the dissertation for the doctor of philosophy award was expected to express an original thesis, that is, it had to contain a contribution to knowledge:

The master's degree is awarded to whoever can skilfully renew and well order what has been learnt, and thus promises to be a useful link in the transmission of knowledge between generations. The doctor's degree is awarded to whoever shows eigentümlichkeiten [personality, peculiarity, originality] and erfindungsvermögen [creativity] in the treatment of academic knowledge. (Wright, 1827; quoted in Clark, 2006: 211)

It was easy to exclude knowledge of the physical world from a university education when it was based on the perceived highest thoughts and writings since antiquity; it was much less easy to exclude it from a university education aimed the pursuit of knowledge. This latter goal provided an opening for the entry of the physical sciences into university education.

There were several other factors supporting that development. First, the defeat of Prussia by Napoleon led some influential people in Prussia to argue that the power of scientific knowledge could be harnessed to serve national goals - they saw knowledge, particularly scientific and technological knowledge, as power (Noble, 1994). Second, the accumulation of scientific knowledge outside universities had gone from strength to strength, and it was becoming increasingly difficult to ignore. Third, philosophy was particularly influential in German universities, and this meant that, institutionally, natural philosophy was well placed to expand.

It may also be relevant that Wilhelm von Humboldt's brother, Alexander von Humboldt, was an eminent scientist and an influential advocate for scientific knowledge, having worked in many countries to establish scientific academies (Wulf, 2015).

Wilhelm von Humboldt believed that the study of philology played an important role in training empirical scientists. For Humboldt, therefore, the physical sciences were built on foundations of philology. The contribution of philology to the training of scientists was even more direct in the following respects. First, the tradition of 'critical thinking' of German philology could be harnessed to support the development of science in university education - science can be seen as the product of empiricism and reason, and reason itself can be seen as the product of logic and critical thinking. Second, the 'academic seminar' had been developed as a process for training philologists in German universities, and this method was adopted for training scientists (Clark, 1989, 2006). Third, the textual analysis of classical philology supported the idea and strategy of reductionism, that is, increasing understanding of the whole by focusing on enlarging understanding of its individual parts, which offered a model for specialization (and reductionism) in the empirical sciences as a strategy for research. Fourth, philology is empirical in that it uses 'hard' text, rather than the immaterial ideas of philosophical enquiry to test truth claims.

The proximate goal of classical philology was the authentication, correction and identification of the intended meaning of text-based knowledge. Its larger goal was to contribute to the stock of texts that were authentic, accurate and conveyed the meaning intended by their authors. This meant that philology was about the accumulation of knowledge, in a quantitative sense. This gave philology a natural affinity with science because the great project of the scientific revolution was to enlarge the stock of knowledge of the natural world (Henry, 2002).

Knowledge is pursued so that it may be found. The success of the pursuit of knowledge can therefore be assessed by the extent of the discovery of new knowledge. In other words, the aim of the pursuit of knowledge is the discovery of knowledge, and 
that meant research. The higher goal of the university became the accumulation of new knowledge and its dissemination (Noble, 1994).

Other Prussian universities followed Berlin's lead, and this model was adopted in other countries as well. There are at least three reasons for this. First, the commitment of German professors to research and publication provided them with a source of reputation not enjoyed by university staff in other universities that restricted themselves to teaching (Clark, 2006). Second, in the latter part of the nineteenth century, German industry was flourishing, and this was attributed, at least in part, to the adoption of research, especially research into the physical sciences. Third, there was a large flow of students from other countries, especially the USA, into German universities, particularly from those wanting training in scientific research, who viewed science as a vocation or at least as a source of employment (Simpson, 1983).

German universities, which had been regarded as the most backward in Europe in the eighteenth century, were transformed during the course of the nineteenth century into those that were viewed as the most successful. They attracted students and scholars from across the world. By the end of the nineteenth century, not only were the German universities seen as being at the leading edge, but also they were the ones that had made most progress. The conclusion was clear: if you wanted to build a successful university, you needed to prioritize the pursuit of knowledge. Consequently, the universities that were established subsequently (that is, most of the universities that exist in the world today) tended to follow the model of the research-led university initiated by Humboldt (Axtell, 2016).

By the beginning of the twentieth century, many universities in the USA had adopted the kind of researcher development programmes that originated in Germany. In the USA, it took the following form. First, it was centred on the PhD - the very title, doctor of philosophy, reflects its origins in Germany, where the philosophy faculties were relatively powerful and where 'natural philosophy' was the traditional term for the study of the natural world, that is, the physical sciences. Second, to be successful, candidates had to provide evidence that they had developed the capacity to make an original contribution to new knowledge (Clark, 2006). Consequently, the distinguishing feature of the $\mathrm{PhD}$ was that it included the requirement for candidates to plan and carry out a research project, and that capacity could be tested against the criterion of whether the outcome was worthy, at least in part, of dissemination by publication. Third, a hierarchy of awards was established with the PhD at the summit, as a research degree that was positioned above the taught degree courses. Setting research training at the highest point of higher education reflected the values and priorities of the new research universities of the USA (and, of course, Germany). Fourth, increasingly, research universities in the USA required candidates for academic posts to have acquired a PhD as evidence of their capacity to contribute to the advancement of knowledge by research (Noble, 1994).

The issue was less clear in the universities that pre-dated the University of Berlin. Those universities, such as Oxford and Cambridge, had their own values, beliefs and rituals. It had taken centuries to transform institutions whose primary role had originally been as seminaries for the Latin Church into institutions whose primary role was to serve the purposes of the students. The ordering of the priorities of these universities was embedded in traditions, structures and practices that were difficult to change. For most of these institutions, the intellectual history of the nineteenth century was one of a battle between those who attached primary importance to the education of students and those who attached primary importance to research. Mainstream Oxford 
and Cambridge resisted the idea of a research-based university until well into the twentieth century.

This resistance to the idea of the research-based university was most clearly articulated in Newman's The Idea of a University (1852). For Newman, the main purpose of a university was to provide a university education, and the main purpose of a university education was to cultivate the mind and hence produce cultured and civilized young men (Newman, 1852; Tight, 2009).

In the early decades of the twentieth century, however, changes were increasingly under way. First, scientists constituted a significant new learned profession, contrasted with the situation at the beginning of the nineteenth century when science (as natural philosophy) was, for the most part, the province of those with the income and/or time to pursue it as a hobby or personal interest. Second, the large flow of students to German universities from other countries, especially the USA, was joined by rapidly expanding numbers of students applying for postgraduate degree courses in those countries where these were available (Simpson, 1983). Third, just as German industrial and military power had accelerated in the first half of the nineteenth century alongside the 'modernization' of its universities, so the industrial and military power of the USA had accelerated in the second half of the nineteenth century alongside the modernization of its universities and their increasing commitment to research. Consequently, Bacon's oft-quoted dictum that 'knowledge is power' acquired a new resonance (Henry, 2002).

In Britain, however, there were still those who harboured a belief in British economic dominance in the world, pointing to the size of its empire, the largest the world had ever known. This belief supported resistance by senior figures in British universities to the adoption of the 'foreign' PhD (Simpson, 1983). However, the experience of the First World War was a convincing demonstration of the growing military might, industrial power and economic strength of Germany and the USA.

Finally, in 1917 a conference of UK universities recommended adoption of the $\mathrm{PhD}$ as a training in research (Simpson, 2009). The first person to be awarded one of the new doctorates from an English university received a DPhil from Oxford in 1919. The agreement reached in 1917 laid the foundation for what is now regarded as the traditional system of researcher development within English universities. The fact that the UK universities agreed to the same regulations for a $\mathrm{PhD}$ entitles it to be called a 'system'. However, particularly in the early years, its implementation was anything but systematic. For example, according to Aldrich (2010: n.p.):

In 1929 Wittgenstein was awarded a PhD by Cambridge University. He had been a student of Russell but left in 1913 without a degree. In 1929 Ramsey was designated his supervisor and Wittgenstein presented as his thesis a work written 10 years before, away from Russell, away from Cambridge and while Ramsey, 14 years his junior, was still at school.

However, 1917 was the turning point, so it is worth being explicit about the meaning of the term 'traditional system of researcher development', which could be interpreted as:

1. the development, through the completion of a PhD, of the capacity to make an original contribution to new knowledge

2. a structure of university education in which research degrees are positioned above taught courses, with the PhD as the highest award for which it is possible to enrol at a university 
3. a course of PhD study that includes the experience of actually planning and conducting research supported by supervision and, usually, a programme of research seminars

4. the development of researchers by trained researchers.

This reflects the triumph of the vision of the research-led university. As it gained ground, the proportion of students who left university for positions in the Anglican Church in Britain declined, and the proportion going into education-based employment steadily rose. By the middle decades of the century, the Humboldtian revolution in UK universities was largely complete, and by that time the majority of UK graduates entered education-based employment upon graduation. They went on to research, further academic study, teacher training, other training, education administration or directly into teaching. When data on the destinations of university graduates was first published in the early 1960s, about two-thirds of the graduates remained in the education system after graduation (Bourner and Rospigliosi, 2008).

The large majority of new graduates were thus engaged in the advancement of knowledge, directly or indirectly, through the accumulation or dissemination of knowledge, and they were prepared for this by the sort of education provided by the direct descendent of the Humboldtian university. This included the dissemination of recent additions to knowledge to the students of the university. It included the development of the students' critical faculties, that is, their ability to test ideas, assertions and evidence as the means by which claims to new knowledge could be evaluated. And it included the development of a questioning attitude as the byproduct of well-honed critical faculties.

By the middle of the twentieth century, British universities had largely accepted the traditional researcher development system centred on the $\mathrm{PhD}$, and had transformed their undergraduate education to support that system. However, it is easy to exaggerate the completeness and the depth of tradition in the 'traditional system of researcher development'.

By the time of the Robbins Report of 1963, the majority of the academics recruited to British universities still had no PhD. The Robbins Report found that 45 per cent of academics recruited in the period 1959-61 had a doctorate. The report also observed that the proportion of university academics with doctorate degrees was rising (Committee on Higher Education, 1963).

However, from the 1960s, there were significant countervailing forces. First, the expansion of higher education, partly a response to the Robbins Report itself; this outstripped the rise in the number of PhDs (Kogan and Kogan, 1983). Second, the expansion of vocational education in British universities. The second half of the twentieth century saw, for example, the development of business schools in universities, which expanded business and management studies in British universities. In recruiting staff to teach vocationally based subjects, greater emphasis was placed on practitioner experience relative to research-based qualifications (Bourner et al., 2001). Third, rebadging the polytechnics as universities in 1992 resulted in a large inflow of university academics from institutions that placed a relatively high value on vocational education, dissemination of knowledge through teaching and the application of knowledge relative to the discovery of new knowledge. The proportion of staff with PhDs was therefore much lower among the polytechnic lecturers than in the pre-1992 universities (Whitburn et al., 1976).

By the start of the twenty-first century, the percentage of academics in British universities with PhDs was therefore probably significantly lower than it had been at the time of the Robbins Report four decades earlier. This is the historical context in 
which many university academics were able to look back to a heyday of the 'traditional system of researcher development' from which contemporary developments could be seen as a departure.

\section{Conclusion}

The reason for writing this article was to report what we discovered from an enquiry into the genealogy of researcher development in British universities. We wanted to be able to contextualize current issues in researcher development, including innovations in researcher development such as the MRes. We draw several main conclusions. There is a hierarchy of esteem in areas of knowledge within universities that has changed over time. In the medieval university, spiritual knowledge was positioned above secular knowledge. Text-based knowledge was most highly regarded, with the Bible, taken by many to be the word of God, the most revered of all. Also, old knowledge was more venerated ('venerable knowledge') than new knowledge. Within the domain of secular knowledge, products of the human mind (logic, rhetoric, grammar, mathematics and so on) occupied a position above knowledge of the physical world, based on fallible human senses. In the early modern university, the position of secular knowledge rose, especially the humanities. By comparison, knowledge of the physical world continued to be less valued. In the modern university, new knowledge of the physical world has become relatively more esteemed than knowledge of products of the human mind (the humanities) and many academics today, would not regard 'spiritual knowledge' as knowledge at all.

There was little that we can recognize as researcher development in the medieval university. Why not? There were at least three reasons. First, old knowledge was revered more than new knowledge. Second, knowledge was, for the most part, treated as allegorical rather than literal. Third, most academics, who were virtually all clerics, were more concerned with 'truth' (a qualitative concept) than the accumulation of new knowledge (a quantitative concept).

Researcher development, in an embryonic form, first appeared in the Renaissance and early modern university in the form of philology. This was much more developed in some universities, mostly in Germany, than in others. Training in philology had a significant influence on the development, in the nineteenth century, of training in the natural sciences through, among other things, the reductionism of textual criticism and the emergence of the research seminar. Then, similar methods of researcher development were applied to other academic subjects more generally.

The 'traditional system' of researcher development, focused on the $\mathrm{PhD}$, is a product of the modern university, and within the modern university it is surprisingly recent. In Britain, for example, it is a development of the first half of the twentieth century, and in many countries it was a development of the second half of the twentieth century. Thus, for example, the first PhD was not awarded in England until after the First World War, and the first PhD in Australia was not awarded until after the Second World War.

These conclusions have several implications. First, there is a need for a change of mindset from the idea that current developments in researcher development are deviations from a time-honoured 'traditional model' of researcher development to a view that we are witnessing a system that is still in the process of developing. What is often viewed as the traditional model of researcher development may, when viewed from the longer perspective, simply be the current position in its continuing development. Second, the pecking order of knowledge may be much less stable than 
it currently appears. In the medieval university, spiritual knowledge was ascendant. The Renaissance and early modern university placed most weight on ethical, aesthetic and social knowledge based on the humanities, and it was only in the modern university that knowledge of the physical world became the most highly valued. Third, it is difficult to understand changes in researcher development without understanding changes in research, and it is difficult to understand that without understanding changes in the advancement of knowledge more generally. It is, in turn, difficult to understand that without understanding changes in knowledge more generally. Figure 1 illustrates this.

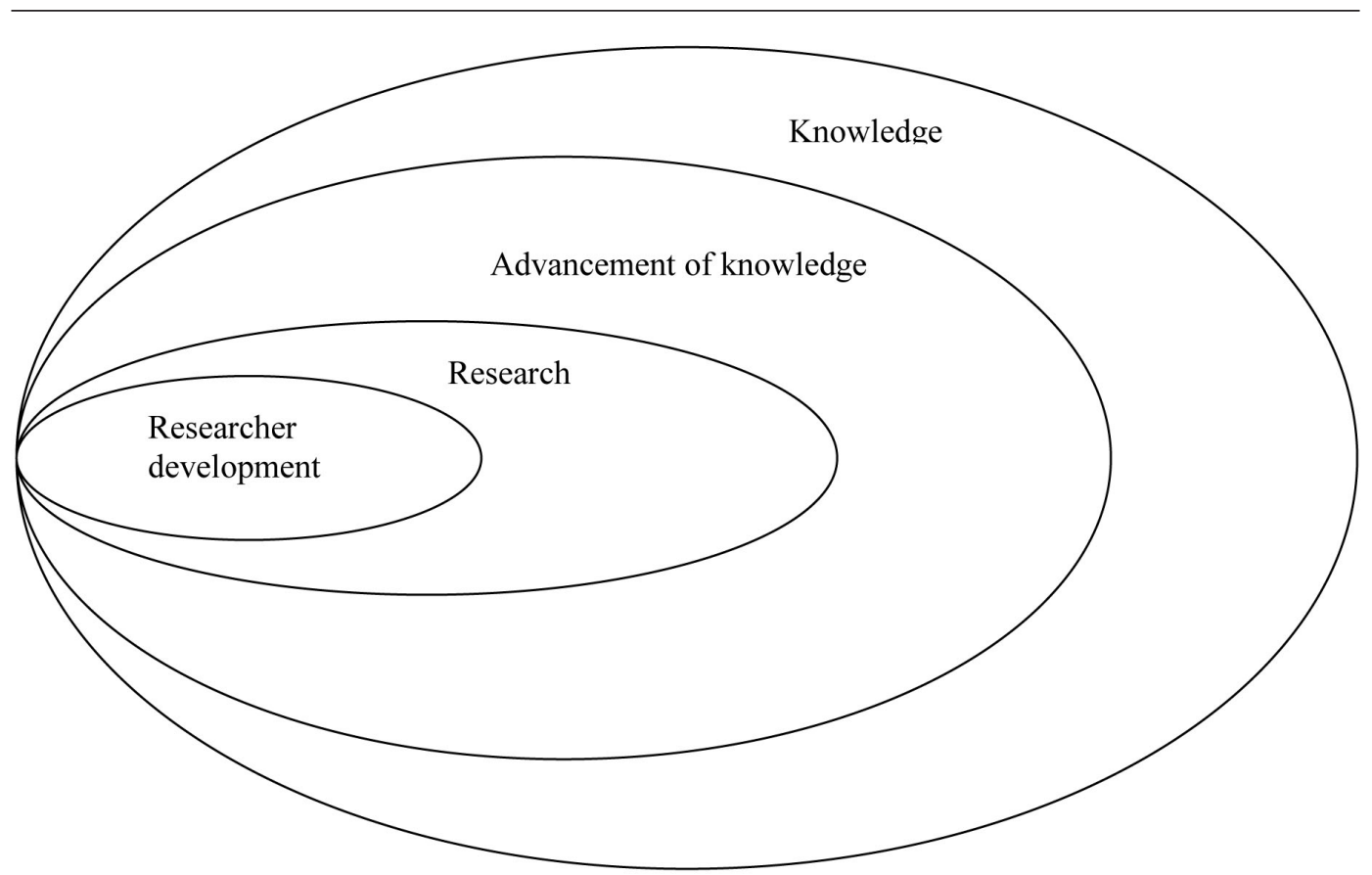

Figure 1: Researcher development within the contexts of research, the advancement of knowledge and knowledge

In other words, researcher development exists within several intellectual contexts, and changes in any of those contexts are likely to impact on researcher development.

These conclusions and their implications raise further questions, which help to provide an agenda for further enquiry. First, when we appreciate that researcher development exists within the contexts of research more generally, the advancement of knowledge more generally and conceptions of knowledge yet more generally, then it becomes apparent that understanding how researcher development is changing can be informed by asking the following questions:

- How are knowledge and conceptions of knowledge changing? What does that imply for researcher development?

- How is the advancement of knowledge more generally changing? What does that imply for researcher development?

- How is research itself changing? What does that imply for researcher development?

Second, if we think of researcher development evolving as a result of changes in the nature of knowledge (and conceptions of knowledge), the advancement of knowledge and research, rather than as deviations from a time-honoured traditional model, then changes in each of these contexts would lead us to explore consequential changes 
in researcher development. This implies that those who are interested in researcher development and the study of researcher development might fruitfully question these intellectual contexts of researcher development. Third, the position of fields of knowledge in the pecking order of esteem within universities seems much less fixed when a longer perspective is taken. Moreover, over that longer perspective, it is possible to see the rise of individual subjects (such as business studies, psychology and engineering) and the fall of other subjects (such as rhetoric, Greek, Latin and philology itself). This raises the question of what do we really understand about the reasons for the rise in fields of knowledge, including what factors are supportive and what are the impediments? Fourth, how applicable is the traditional model of researcher development, which emerged in the context of subject-centred knowledge, to new fields of knowledge such as practice-led, or mode 2 knowledge (Gibbons et al., 1994)?

Researcher development has a relatively short history in universities, and the emergence of the researcher developer as a 'third-space' profession is a very recent phenomenon. Hopefully, this article will help those who work in this field as researchers or practitioners to locate their work within its long-term historical context.

\section{Notes on the contributors}

Asher Rospigliosi is Principal Lecturer in Digital Transformation, Digital Marketing and the Digital Economy at the University of Brighton, UK. He is co-editor of the journal Interactive Learning Environments and his most recent book is Leading Issues in Social Media Research (ACPIL, 2015).

Tom Bourner is Emeritus Professor of Personal and Professional Development at the University of Brighton, UK. When he retired from paid employment by the university, he was Head of Research in the Business School and led the Management Development Research Unit.

\section{References}

Aldrich, J. (2010) 'The mathematics PhD in the United Kingdom: Historical notes for the Mathematics Genealogy Project'. Online. www.economics.soton.ac.uk/staff/aldrich/PhD.htm (accessed 28 January 2019).

Alexiou, M. (1990) 'Greek philology: Diversity and difference'. In Ziolkowski, J. (ed.) On Philology. University Park: Pennsylvania State University Press, 53-61.

Arnold, M. (1869) Culture and Anarchy: An essay in political and social criticism. London: Smith, Elder and Co.

Ashby, E. (1958) Technology and the Academics: An essay on universities and the scientific revolution. London: Macmillan.

Axtell, J. (2016) Wisdom's Workshop: The rise of the modern university. Princeton, NJ: Princeton University Press.

Bartlett, R. (1993) The Making of Europe: Conquest, colonization and cultural change, 950-1350. London: Allen Lane.

Bod, R. (2013) A New History of the Humanities: The search for principles and patterns from antiquity to the present. Oxford: Oxford University Press.

Bourner, T., Bowden, R. and Laing, S. (2001) 'Professional doctorates in England'. Studies in Higher Education, 26 (1), 65-83.

Bourner, T., Heath, L. and Rospigliosi, P.A. (2014) 'Research as a transferable skill in higher education'. Higher Education Review, 46 (2), 20-46.

Bourner, T. and Rospigliosi, P.A. (2008) 'Forty years on: Long-term change in the first destinations of graduates'. Higher Education Review, 41 (1), 36-59.

Burke, P. (1997) The Renaissance. 2nd ed. Basingstoke: Macmillan.

Burke, P. (2016) What is the History of Knowledge? Cambridge: Polity Press.

Burnett, C. (1997) The Introduction of Arabic Learning into England. London: British Library. 
Clark, W. (1989) 'On the dialectical origins of the research seminar'. History of Science, 27 (2), 111-54.

Clark, W. (2006) Academic Charisma and the Origins of the Research University. Chicago: University of Chicago Press.

Cobban, A.B. (1975) The Medieval Universities: Their development and organization. London: Methuen.

Cobban, A.B. (1988) The Medieval English Universities: Oxford and Cambridge to c.1500. London: Routledge.

Committee on Higher Education (1963) Higher Education: Report of the Committee appointed by the Prime Minister under the Chairmanship of Lord Robbins, 1961-63. London: HMSO.

Curtis, M.H. (1959) Oxford and Cambridge in Transition, 1558-1642. Oxford: Clarendon Press.

De Ridder-Symoens, H. (ed.) (1992) A History of the University in Europe: Volume 1: Universities in the Middle Ages. Cambridge: Cambridge University Press.

De Ridder-Symoens, H. (ed.) (1996) A History of the University in Europe: Volume 2: Universities in early modern Europe (1500-1800). Cambridge: Cambridge University Press.

Elton, L. (1992) 'Research, teaching and scholarship in an expanding higher education system'. Higher Education Quarterly, 46 (3), 252-68.

Freeman, C. (2002) The Closing of the Western Mind: The rise and fall of reason. London: Heinemann.

Gibbons, M., Limoges, C., Nowotny, H., Schwartzman, S., Scott, P. and Trow, M. (1994) The New Production of Knowledge: The dynamics of science and research in contemporary societies. London: SAGE Publications.

Google Books Ngram (2019) Online. https://books.google.com/ngrams/graph?content=researcher +development\&case_insensitive=on\&year_start=1900\&year_end=2010\&corpus=15\&smoothing $=3 \&$ share $=\&$ direct_url $=\mathrm{t} 4 \% 3 \mathrm{~B} \% 2 \mathrm{Cresearcher} \% 20$ development $\% 3 \mathrm{~B} \% 2 \mathrm{Cc0} \% 3 \mathrm{~B} \% 2 \mathrm{Cs} 0 \% 3 \mathrm{~B} \% 3 \mathrm{Bre}$ searcher\%20development\%3B\%2Cc0\%3B\%3BResearcher\%20Development\%3B\%2Cc0 (accessed 3 February 2019).

Grant, E. (2004) Science and Religion, 400 BC to AD 1550: From Aristotle to Copernicus. Westport, CT: Greenwood Press.

Green, V.H.H. (1974) A History of Oxford University. London: Batsford.

Hannam, J. (2009) God's Philosophers: How the medieval world laid the foundations of modern science. London: Icon Books.

Harkins, F.T. (2015) 'Filiae Magistri: Peter Lombard's Sentences and medieval theological education "on the ground"'. In Rosemann, P.W. (ed.) Mediaeval Commentaries on the Sentences of Peter Lombard. Leiden: Brill, 26-78.

Henry, J. (2002) Knowledge is Power: Francis Bacon and the method of science. Cambridge: Icon Books.

Hiatt, A. (2004) The Making of Medieval Forgeries: False documents in fifteenth-century England. London: British Library and University of Toronto Press.

Humboldt, W. von (1970) 'On the spirit and organisational framework of intellectual institutions in Berlin'. Minerva, 8, 242-67.

Kogan, M. and Kogan, D. (1983) The Attack on Higher Education. London: Kogan Page.

McGrath, A. (2001) In the Beginning: The story of the King James Bible and how it changed a nation, a language and a culture. London: Hodder and Stoughton.

Miles, R. (2010) Ancient Worlds: The search for the origins of Western civilization. London: Allen Lane.

Newman, J. (1852) The Idea of a University. London: Longman.

Noble, K.A. (1994) Changing Doctoral Degrees: An international perspective. Buckingham: Society for Research into Higher Education and Open University Press.

Pedersen, O. (1997) The First Universities: Studium generale and the origins of university education in Europe. Cambridge: Cambridge University Press.

Perkin, H. (1997) 'History of universities'. In Goodchild, L.F. and Wechsler, H.S. (eds) The History of Higher Education. 2nd ed. Boston: Pearson, 3-34.

Pollock, S. (2009) 'Future philology? The fate of a soft science in a hard world'. Critical Inquiry, 35 (4), 931-61.

Potok, C. (1985) Davita's Harp. New York: Knopf.

Rospigliosi, P.A., Bourner, T. and Heath, L. (2016) 'Universities' engagement with vocationalism: Historical perspective'. International Journal for Research in Vocational Education and Training, 3 (3), 185-211. 
Rüegg, W. (ed.) (2004) A History of the University in Europe: Volume 3: Universities in the nineteenth and early twentieth centuries (1800-1945). Cambridge: Cambridge University Press.

Simpson, R. (1983) How the PhD Came to Britain: A century of struggle for postgraduate education. Guildford: Society for Research into Higher Education.

Simpson, R. (2009) The Development of the PhD Degree in Britain, 1917-1959 and Since: An evolutionary and statistical history in higher education. Lewiston, NY: Edwin Mellen Press.

Tight, M. (2009) The Development of Higher Education in the United Kingdom since 1945. Maidenhead: Open University Press.

Turner, J. (2014) Philology: The forgotten origins of the modern humanities. Princeton, NJ: Princeton University Press.

Whitburn, J., Mealing, M. and Cox, C. (1976) People in Polytechnics: A survey of polytechnic staff and students, 1972-3 (Research into Higher Education Monograph 27). Guildford: Society for Research into Higher Education.

Whitchurch, C. (2008) 'Shifting identities and blurring boundaries: The emergence of third space professionals in UK higher education'. Higher Education Quarterly, 62 (4), 377-96.

Wright, J.M.F. (appeared anonymously) (1827) Alma Mater; or, Seven years at the University of Cambridge. By a Trinity-man. 2 vols. London: Black, Young and Young.

Wulf, A. (2015) The Invention of Nature: The adventures of Alexander von Humboldt, the lost hero of science. London: Hodder and Stoughton. 